\title{
Scotch broom (Cytisus scoparius) modifies microenvironment to promote nonnative plant communities
}

\author{
David R. Carter · Robert A. Slesak • Timothy B. Harrington • David H. Peter • \\ Anthony W. D'Amato
}

Received: 9 February 2018/Accepted: 21 November 2018/Published online: 24 November 2018

(C) Springer Nature Switzerland AG 2018

\begin{abstract}
Scotch broom [Cytisus scoparius (L.) Link] is a globally important nitrogen (N)-fixing invasive plant species that has potential to alter soil water dynamics, soil chemistry, and plant communities. We evaluated the effects of Scotch broom on soil moisture, soil chemistry, soil temperature, photosynthetically active radiation (PAR), and vegetation communities over 4 years at a site recently harvested for timber. Treatments of Scotch broom (either present via planting or absent) and background vegetation (either present or absent via herbicide treatments) were applied to $4 \mathrm{~m}^{2}$ plots. Background vegetation was associated with the greatest decrease of soil water content (SWC) among treatments. During the driest year, Scotch broom showed some evidence of increased early-and late-season soil water usage, and, briefly, a high usage relative to background
\end{abstract}

Electronic supplementary material The online version of this article (https://doi.org/10.1007/s10530-018-1885-y) contains supplementary material, which is available to authorized users.

\section{R. Carter $(\square)$}

Department of Forest Resources and Environmental Conservation, Virginia Polytechnic Institute and State University, 228G Cheatham Hall, Blacksburg, VA 24060, USA

e-mail: david.r.j.carter@gmail.com

\section{R. A. Slesak}

Department of Forest Resources, University of Minnesota, 1530 Cleveland Ave N, Saint Paul, MN 55108, USA vegetation plots. On a percent cover basis, Scotch broom had a substantially greater negative influence on SWC than did background vegetation. Surprisingly, Scotch broom was not consistently associated with increases in total soil $\mathrm{N}$, but there was evidence of increasing soil water $\mathrm{N}$ when Scotch broom was present. Scotch broom-only plots had greater concentrations of soil water magnesium $\left(\mathrm{Mg}^{2+}\right)$ and calcium $\left(\mathrm{Ca}^{2+}\right)$ than other treatments. On a percent cover basis, Scotch broom had a uniquely high demand for potassium $\left(\mathrm{K}^{+}\right)$relative to the background vegetation. Average soil temperature was slightly greater, and soil surface PAR lower, with Scotch broom present. Scotch broom-absent plots increased in species diversity and richness over time, while Scotch broompresent plots remained unchanged. Scotch broom presence was associated with an increase in cover of nonnative sweet vernalgrass (Anthoxanthum odoratum L.). Scotch broom generated positive feedbacks with resource conditions that favored its dominance and the establishment of nonnative grass.

T. B. Harrington · D. H. Peter

USDA Forest Service, Pacific Northwest Research

Station, 3625 93rd Avenue Southwest, Olympia, WA 98512, USA

A. W. D’Amato

Rubenstein School of Environment and Natural

Resources, University of Vermont, Burlington, VT 05405, USA 
Keywords Soil properties - Pacific Northwest .

Extended growing season $\cdot$ Soil water

\section{Introduction}

Native to the Mediterranean (Tutin et al. 1968), Scotch broom (Cytisus scoparius (L.) Link) is an invasive species of major ecological concern (Bossard and Rejmanek 1994). Now found on six continents (Potter et al. 2009), Scotch broom is capable of dominating sites (Bossard and Rejmanek 1994; Richardson et al. 2002) and altering ecosystem function (Haubensak and Parker 2004; Slesak et al. 2016). Scotch broom is an aggressive invader in early-successional coast Douglas-fir (Pseudotsuga menziesii (Mirb.) Franco var. menziesii) forests of the Pacific Northwest (PNW), where this study was conducted. Scotch broom is well-adapted to the climate and summer droughts characteristic of the region. High seed production coupled with a ballistic seed dispersal strategy and decades-long seed viability, allows this species to rapidly dominate and persist on a site for many years (Bossard and Rejmanek 1994).

The dramatic annual fluctuation of precipitation characteristic of Mediterranean climates, like that of the PNW, results in soil water being a primary limiting resource during the growing season (Brubaker 1980). Scotch broom has been found to be a strong competitor for soil water in similar systems (Richardson et al. 2002; Watt et al. 2003) and to have a high evapotranspiration (ET) rate, owing to its large size (Boldrin et al. 2017). Conversely, Scotch broom possesses several traits that make it tolerant and avoidant of drought conditions: high root length density, low leaf area to root mass ratio, low specific leaf area, photosynthetic stems, and a drought-deciduous phenology (Bannister 1986; Bossard and Rejmanek 1994; Matías et al. 2012; Boldrin et al. 2017). As a result, Scotch broom is considered highly adapted to droughtprone, Mediterranean climates, likely facilitating its dominance of sites in those regions around the globe. Given these potentially conflicting attributes of Scotch broom - as a plant with the ability to deplete soil water due to its high ET and as a plant that avoids excessive soil water usage during peak drought conditionsquestions remain about Scotch broom's influence on soil water.
Generally the traits that enable a plant species to become invasive - high growth rate and leaf nutrient concentrations-are traits that also increase decomposition rates and nutrient cycling (Ehrenfeld et al. 2001; Ehrenfeld 2003; Allison and Vitousek 2004). Invasive $\mathrm{N}$-fixing plant species generally have a greater impact on patterns of $\mathrm{N}$-cycling (Vilà et al. 2011; Broadbent et al. 2017) than non-N-fixing plants. Compounding this, edaphically young sites, like those commonly found in recently glaciated regions of the western PNW, generally possess an N:P stoichiometry favorable for biological N-fixation (Williams 1981). Similarly, greater soil phosphorus is often correlated with plant species invasion (Weidenhamer and Callaway 2010).

Several studies have investigated the impact of Scotch broom invasion on soil properties and nutrient cycling with varying results. Increases in soil C, N, and $\mathrm{P}$ have been documented following invasion in several studies (Wheeler et al. 1987; Fogarty and Facelli 1999; Haubensak and Parker 2004; Caldwell 2006; Grove et al. 2015), whereas others have reported no change in $\mathrm{N}$ and a decrease in P (Shaben and Myers 2009). Caldwell (2006) found that soils under Scotch broom had higher activities of two soil enzymes involved in the acquisition of phosphorus. It is still not known whether greater $\mathrm{P}$ depletion in the presence of legumes is due to plant-or Bradyrhizobium-(bacterial symbionts of Scotch broom) demands (Hardy and Havelka 1976). N-fixation is considered a P-demanding process, yet, other studies have demonstrated no increase in Bradyrhizobium fixation rates but an increase in host biomass (Crews 1993) under P fertilization.

Dassonwille et al. (2008) found a general tendency for invaders to increase soil nutrient pools on lowfertility sites and decrease soil nutrient pools on high quality sites. Comparisons made by Slesak et al. (2016) between two sites of contrasting soil textures and nutrient availabilities showed changes in soil chemical properties in the presence of Scotch broom may be site-dependent. Any change in nutrient cycling caused by an invasive species has the potential to alter the distribution and availability of nutrients, thereby influencing plant communities (Prober and Lunt 2009).

Invasive species can possess traits that facilitate competitive success over native plant species. Such traits include: plastic phenologies, rapid growth, and extensive seedbank accrual (Knapp and Seastedt 1986; 
Beatty and Sholes 1988; Wearne and Morgan 2006; Zhou et al. 2009; Matías et al. 2012; Boldrin et al. 2017). Soil nutrient enrichment, particularly N, associated with plant invasions has been hypothesized to facilitate the establishment and success of other nonnative invaders (Weidenhamer and Callaway 2010). Invasions can be so severe as to lead to drastic modification or loss of native plant communities (Ruesink et al. 1995). Similarly, Scotch broom has caused changes in plant community composition and richness (Parker et al. 1997) through several mechanisms. For example, the rapid growth rate of Scotch broom facilitates its dominance over competing species (Fogarty and Facelli 1999). The resultant shade and litter accumulation under large Scotch broom affect soil temperature and, correspondingly, conditions affecting germination for other species (Waterhouse 1988; Wearne and Morgan 2004). Grove et al. $(2012,2015)$ partially attributed reductions in Douglas-fir growth and survival to increases in nitrophyllic forbs and grasses to a fertilization effect driven by the presence of Scotch broom.

Native plant species have also been found to inhibit the competitive success of invaders, however (Levine et al. 2004). Native grasses have been found to inhibit Scotch broom development and growth, presumably because of competition for soil water (Harrington 2011; Lang et al. 2017). These contrasting findings of Scotch broom influencing plant communities and being inhibited by native species highlight the importance of examining the patterns and impacts of Scotch broom invasion within plant communities.

In this study, we examined the effects of Scotch broom on its local environment in a recently harvested Douglas-fir forest: a common location of Scotch broom invasion. We did this by separating the Scotch broom influence on the soil environment from that of other vegetation during the first 4 years of stand establishment. The treatments were also designed, in part, to reflect the conditions commonly found in these systems post-clear-cut. We expected Scotch broom to be associated with (i) an increased utilization of soil water (timing and magnitude of summer drawdown) compared to background vegetation; (ii) increases in soil water cations and soil nutrients; and (iii) reduced soil temperature and PAR relative to background vegetation. Furthermore, we predicted (iv) the growth of Scotch broom to be inhibited by the presence of competing vegetation compared to when it was grown in isolation; and (v) increases in nonnative plant species cover and decreases in native plant cover in the presence of Scotch broom. Lastly, we expected (vi) Scotch broom to have greater decreasing effects on soil water content and soil nutrient variables relative to native plants on a per unit of cover basis.

\section{Methods}

Study site

The study was located near Matlock, WA, USA $\left(47.215^{\circ} \mathrm{N}, 123.417^{\circ} \mathrm{W}\right)$ at a recently harvested forest site. The soils are classified as a sandy-skeletal, mixed, mesic, Dystric Xerorthents formed in glacial outwash (Soil Survey Staff, USDA-NRCS; Table 1). The local climate is Mediterranean with a winter rainy season and seasonal drought during the growing season (often $>2$ months), with coastal fog commonly persisting until late morning. Average annual precipitation is $238 \mathrm{~cm} \mathrm{year}^{-1}$ (1981-2010), only $22 \%$ of which $(52 \mathrm{~cm})$ occurs during the growing season (April-September) (PRISM Climate Group 2017). The dominant plant association is western hemlock/ salal/beargrass (Tsuga heterophylla (Raf.) Sarg./ Gaultheria shallon Pursh/Xerophyllum tenax (Pursh) Nutt.) (Henderson et al. 1989). The most abundant species found on the site at the time of the experiment were Saskatoon serviceberry (Amelanchier alnifolia (Nutt.) Nutt. Ex M. Roem.), California blackberry (Rubus ursinus Cham. and Schltdl.), oxeye daisy (Leucanthemum vulgare Lam.), sweet vernalgrass (Anthoxanthum odoratum L.), and salal (Gaultheria shallon Pursh).

Prior to harvesting, the forest on the site was dominated by a natural stand of coast Douglas-fir averaging 60 years in age. The understory was uniform, dominated by salal, swordfern (Polystichum munitum (Kaulf.) C. Presl.), bracken fern (Pteridium aquilinum) and California blackberry (Peter and Harrington 2018). The pre-harvest Douglas-fir stand contained Scotch broom, which was likely introduced in 1996 during a salvage thinning of ice-storm damaged trees (Randall Greggs, personal communication). The stand was then clearcut in December 2011 and did not receive any vegetation control treatment prior to harvest. Trees were felled, bucked, and delimbed with chainsaws, and logs were extracted via a 
Table 1 Pre-treatment soil properties to a depth of $20 \mathrm{~cm}$

\begin{tabular}{ll}
\hline Soil property & Mean $( \pm \mathrm{SE})$ \\
\hline Bulk density $\left(\mathrm{Mg} \mathrm{m}^{-3}\right)^{\mathrm{a}}$ & $1.10(0.19)$ \\
Coarse fragments $(\%$ of mass) & $68(5)$ \\
Soil texture $(\%$ sand/silt/clay) & b \\
Total carbon $(\%)^{\mathrm{c}}$ & $11.1(2.8)$ \\
Total nitrogen $(\%)^{\mathrm{c}}$ & $0.4(0.3)$ \\
Available phosphorus $\left(\mathrm{mg} \mathrm{kg}^{-1}\right)^{\mathrm{d}}$ & $5(3)$ \\
Extractable calcium $\left(\mathrm{mg} \mathrm{kg}^{-1}\right)^{\mathrm{e}}$ & $197(93)$ \\
Extractable magnesium $\left(\mathrm{mg} \mathrm{kg}^{-1}\right)^{\mathrm{e}}$ & $46(19)$ \\
Extractable potassium $\left(\mathrm{mg} \mathrm{kg}^{-1}\right)^{\mathrm{e}}$ & $99(30)$
\end{tabular}

Values are averages for the 24 plots measured for soil chemistry

${ }^{\text {a }}$ Determined with the sand cone method at 0-15 cm depth

${ }^{\mathrm{b}}$ Determined with the hydrometer method

${ }^{\mathrm{c}}$ Measured with dry combustion

${ }^{\mathrm{d}}$ Determined with Bray method

${ }^{\mathrm{e}}$ Determined with Mehlich extraction

tracked loader that stayed on the designated machine trails. The plots for this study were intentionally located on a machine trail $(\sim 10 \mathrm{~m}$ wide $)$ given our assumption that the associated soil disturbance would further facilitate the establishment of Scotch broom as these conditions typically serve as the epicenter for the species' invasion of forest sites in the PNW.

A completely randomized $2 \times 2$ factorial experimental design was implemented to compare four treatments: a bare-ground control, Scotch broom only, background vegetation only, and Scotch broom and background vegetation. Forty $2 \times 2$-m plots were installed $5 \mathrm{~m}$ apart ( $\mathrm{n}=10 /$ treatment). A subset of six replications of each treatment, were used to test the effects of Scotch broom on soil water content (SWC; $\mathrm{m}^{3} \mathrm{~m}^{-3}$ ), soil water chemistry $\left(\mathrm{mg} \mathrm{L}^{-1}\right)$, soil nutrient concentrations $\left(\mathrm{mg} \mathrm{kg}^{-1}\right)$, and soil temperature $\left({ }^{\circ} \mathrm{C}\right)$. PAR (\% of full sun) was measured in each plot. The background-vegetation-only and Scotch-broom-andbackground-vegetation treatments $(n=20)$ were used to test the effect of Scotch broom presence on vegetation communities (percent cover (\%)). This same subset was used to test the effects of background vegetation on the growth of Scotch broom [height $(\mathrm{cm})$, crown width $(\mathrm{cm})$, and canopy volume $\left.\left(\mathrm{m}^{3}\right)\right]$.

One-year-old container grown Scotch broom were planted in April 2013 in the center of $2 \times 2-\mathrm{m}$ plots randomly assigned as Scotch broom-only or Scotch broom-and-vegetation treatments. The containerized Scotch broom seedlings were grown in potting soil (Sunshine mix \#2, Sun-Gro Horticulture Distribution Inc., Bellevue, Washington). The mean ( \pm SE) initial height, geometric mean crown width, and crown volume at planting were $117.1 \pm 7.0 \mathrm{~cm}$, $54.04 \pm 4.3 \mathrm{~cm}$, and $0.2 \pm 0.04 \mathrm{~m}^{3}$. Treatments with no background vegetation present were created by killing the vegetation with a mixture of glyphosate and triclopyr herbicides prior to planting and annually thereafter to totally control all other vegetation within the plot throughout the study period. Planted Scotch broom were shielded from exposure to the herbicide treatments. Naturally germinating Scotch broom plants were periodically removed by hand from all plots to isolate the influence of the treatments. We utilized herbicides to control vegetation because such treatments are effective at completely killing the target plants, minimizing artifacts of soil disturbance associated with other techniques (e.g., pulling of weeds), and having limited effects on microbial communities (Weidenhamer and Callaway 2010) even at concentrations much higher than prescribed (Busse et al. 2001).

\section{Soil water content}

Soil moisture sensors (model EC-5, METER Group, Inc., Pullman WA, USA) were installed horizontally at $30 \mathrm{~cm}$ depth approximately $50 \mathrm{~cm}$ from plot center. Volumetric soil water content (SWC) was measured every 2-3 weeks during each growing season with a ProCheck datalogger (METER Group, Inc., Pullman WA, USA). Calibration equations developed with soil from the nearby Matlock Long-Term Soil Productivity study (Harrington and Schoenholtz 2010) were used to calculate SWC.

\section{Soil water chemistry}

Soil water cations (total $\mathrm{N}, \mathrm{Mg}^{2+}, \mathrm{Ca}^{2+}, \mathrm{K}^{+}$, and $\mathrm{PO}^{4+}$ ) were evaluated from samples collected periodically throughout the growing season using tension lysimeters to detect changes in soil water chemistry in the rooting zone below Scotch broom (when present). Tension lysimeters were fabricated with high-flow $(100 \mathrm{kPa})$ porous ceramic cups (maximum pore size of $2.5 \mu \mathrm{m}$; Soil Moisture Corp., Santa Barbara, 
California) attached to $5.08 \mathrm{~cm}$ polyvinyl chloride tubing. Lysimeters were installed in six plots per treatment $(n=6$ plots $\times$ treatments $=24)$. The lysimeters were placed $30 \mathrm{~cm}$ away from the center of each plot at a $45^{\circ}$ angle to a depth of $30 \mathrm{~cm}$, enabling collection of soil water from immediately below plot center. To prevent the flow of water along the outside of the PVC, about $240 \mathrm{ml}$ of bentonite pellets were applied around the point at which the PVC entered the soil. Soil solution samples were collected monthly from each lysimeter during April-October of 2015 and $2016(\mathrm{n}=288)$. At each sample time, lysimeters were first purged of any water, and then primed to $-50 \mathrm{kPa}$ with a hand pump. Samples were collected 2-3 days after priming the lysimeters. The samples were kept frozen prior to shipping to the University of Washington Analytical Laboratory, Seattle, WA for estimation of cation concentrations. The samples were filtered and analyzed using an Inductively Coupled Argon Plasma Mass Spectrometer (Thermo Scientific Co. model 61E).

\section{Soil nutrients}

Soil samples were collected at treatment initiation and at the end of the experiment to assess treatment effects on soil chemical properties. Mineral soil samples were collected with a bucket auger at three locations near plot center to a depth of $20 \mathrm{~cm}$. Samples were composited in the field and a subsample was collected in a plastic bag and transported to the lab for processing. All samples were air-dried, sieved to pass a $2 \mathrm{~mm}$ mesh, and archived prior to chemical analysis. Pre-and post-treatment samples were analyzed at the same time to account for any analytical error at time of analysis. Total soil $\mathrm{C}$ and $\mathrm{N}$ were measured on a $1-\mathrm{g}$ pulverized subsample with dry combustion using a LECO Dumas combustion technique on a Fisons NA1500 NCS Elemental Analyzer (ThermoQuest Italia, Milan, Italy). Available soil $\mathrm{P}$ was estimated using the Bray extraction followed by calorimetric estimation of $\mathrm{P}$ on a spectrophotometer (Spectronic 20 Genesys, Model 4001, Thermo Electron Corporation). The Mehlich method (Mehlich 1984) was used to extract soil $\mathrm{Ca}, \mathrm{Mg}$, and $\mathrm{K}$, and extract concentrations were measured with inductively coupled plasma spectroscopy (Varian Vista MPX, Varian, Palo Alto, CA, USA). All estimates are reported on an oven dry $\left(105{ }^{\circ} \mathrm{C}\right)$ basis.
Soil temperature and photosynthetically active radiation

Temperature sensors (iButton model DS1921G, Maxim Integrated, San Jose CA, USA) were installed near the center of each plot at a depth of $5 \mathrm{~cm}$. Soil temperature was logged at 2-h intervals and data were downloaded every 4-6 months.

A ceptometer (model AccuPAR LP-80, METER Group, Inc., Pullman WA, USA) was used to measure PAR as an index of light availability for vegetation. PAR measurements were taken in each plot along 2 east-west transects that were $2.2 \mathrm{~m}$ apart. An abovecanopy reading was taken immediately prior to taking below-canopy readings for a given plot. Three belowcanopy readings at $0.5 \mathrm{~m}$ height facing south were taken at 0,1 , and $2 \mathrm{~m}$ along each transect. Measurements of PAR were taken within $2 \mathrm{~h}$ of solar noon and within several weeks of the summer solstice in 2015 and 2016. Hereafter, ' $\mathrm{PAR}_{\mathrm{B}}$ ' refers to below-canopy PAR expressed as a percentage of the above-canopy reading.

\section{Growth}

Scotch broom height $(\mathrm{cm})$ and crown width $(\mathrm{cm})$ were measured five times over the duration of the study: April 2013, January 2014, November 2014, November 2015, and November 2016. Geometric mean crown width was calculated using the following equation:

$G M W=\sqrt{ }(\mathrm{a} * \mathrm{~b}) ;$

where $G M W=$ geometric mean crown width, $\mathrm{a}=$ crown width 1 , and $\mathrm{b}=$ crown width 2 .

Height and the two crown widths were converted to canopy volume $\left(\mathrm{m}^{3}\right)$ using the equation from Thorne et al. (2002):

$C V=2 / 3 \pi \mathrm{h}(\mathrm{a} / 2 * \mathrm{~b} / 2) ;$

where $C V=$ crown volume, $\mathrm{h}=$ height, $\mathrm{a}=$ crown width 1 , and $\mathrm{b}=$ crown width 2 .

Vegetation communities

Background-vegetation-only and Scotch broom-andbackground-vegetation plots $(n=20)$ were used to assess the impact of Scotch broom on vegetation communities. Percent cover of each vascular plant 
species was visually estimated within each $4-\mathrm{m}^{2}$ plot in July of 2014, 2015, and 2016.

\section{Analysis}

Models predicting soil water content (SWC), soil water chemistry, soil temperature (monthly minimum, maximum and mean), and Scotch broom growth were fit using the gls function in the nlme package (Pinheiro et al. 2013) in R v 3.4.0 (R Core Team 2017). Data were analyzed using a first-order auto-regressive correlation structure for repeated-measures ANOVAs to account for temporal autocorrelation. Post-hoc comparisons were made using the least squares means (LS means) function in the lsmeans package (Lenth 2016). $P$ values were adjusted using the Tukey method to avoid spurious results. The statistical significance threshold was $\alpha=0.1$ for all analyses because of low statistical power associated with the level of replication and high inherent variability in some of the variables (e.g., soil water nutrient concentrations).

The initial SWC per sensor in 2013 was used as an additive covariate when predicting SWC to account for any inherent plot-level variation in soil moisture at the onset of the study. The main effects of bi-weekly period, Scotch broom, vegetation, and their interactions were used as predictors. Data were analyzed within-year and pairwise comparisons made within biweekly periods when models indicated the presence of significant treatment effects.

Soil water chemistry samples were compiled into "early-" (April through June) and "late-season" (August through October) groups within-years for analysis. This was done because consistent sampling among the lysimeters was not possible during the annual summer droughts when soil water was not available for collection. The main effects of season, Scotch broom (present or absent), background vegetation (present or absent), and their interactions were used as predictors. Total $\mathrm{N}$ in 2015 and 2016 and early-season $\mathrm{Mg}$ in 2015 were log-transformed for analyses to meet assumptions of normality and homogeneity. Data were analyzed within-year and pairwise comparisons made within-season.

Effects of treatment on soil nutrients were assessed by calculating the absolute change in soil chemical parameters which was calculated as the difference between pretreatment and post-treatment values, where positive values indicate gains and negative values indicate reductions. Pretreatment values were used as covariates in the analysis to account for differences in relative initial pool size. If the covariate was not significant, then it was dropped from the model. We also conducted $t$ tests within each treatment to independently assess if any change over time was significantly different from zero.

Daily measurements of soil temperatures were converted to monthly minimum, maximum, or mean values per plot. The main effects of month, Scotch broom, vegetation, and their interactions were used as predictors. Data were analyzed within-year and pairwise comparisons were made within-month.

PAR $_{\mathrm{B}}$ was analyzed using the main effects of year (2015 and 2016; as a factor), Scotch broom, vegetation, and their interactions as predictors. All 10 replications of the four treatments were used to analyze $\mathrm{PAR}_{\mathrm{B}}$.

Initial height, geometric mean crown width, and canopy volume were used as additive covariates when predicting height, geometric mean crown width, and canopy volume growth, respectively. The responses and their covariates were log-transformed. The main effects of treatment (Scotch broom only and Scotch broom and vegetation), measurement period, and their interaction were used as predictors. Pairwise comparisons were made within measurements. Effects of Scotch broom presence on vegetation cover were analyzed using the plots that contained Scotch broomand-vegetation and plots that contained only vegetation $(\mathrm{n}=20)$. The bare-ground and Scotch broomonly treatments were removed from analyses. Furthermore, in this reduced set of plots, percent cover of Scotch broom was removed from analyses to focus on its effects on community composition.

Percent cover data were converted to relative abundances to analyze the $\beta$-diversity-or dissimilarities, using Sorenson's distances - and predicted using a two-way interaction of treatment and year in a multivariate ANOVA using the Adonis function in the vegan package in $\mathrm{R}$ (Oksanen et al. 2017). This was done to not only measure dissimilarities between treatments and years but also to justify further analyses.

The data were then analyzed for changes in biodiversity and changes in the percent cover of native and nonnative species and the percent cover of native and nonnative species by growth forms-forbs, grasses, sedges, and woody perennials. Changes in 
biodiversity were assessed by converting percent cover to the Simpson, Shannon-Wiener, and richness indices using the diversity function in the vegan package (Oksanen et al. 2017). The effects of treatment and year were then analyzed using the gls function in the nlme package (Pinheiro et al. 2013).

Biodiversity responses were analyzed using an auto-regressive correlation structure for repeatedmeasures ANOVAs. Post-hoc comparisons were made within-year using the least squares means (LS means) function in the lsmeans package (Lenth 2016).

Absolute changes in percent cover of native and nonnative species by growth form, respectively, were analyzed over the study duration. These values were calculated by grouping species accordingly and subtracting the total cover of groups in 2014 (the first year of percent cover data) from the percent cover of native or nonnative species in 2016. Native and nonnative percent cover values were analyzed in two-sample $t$ tests. Native and nonnative growth form data were analyzed in an ANOVA with treatment and growth form predicting percent cover.

We related percent cover data of vegetation and Scotch broom, respectively, to the aforementioned soil measurements in an attempt to identify differences unique to Scotch broom relative to vegetation on a unit of percent cover basis. The percent cover estimates that were taken annually from 2014 to 2016 were related to SWC (2014-2016), soil water chemistry (2015 and 2016), and soil nutrient estimates (2016) that corresponded to those same years. SWC and soil water chemistry estimates were tested in mixed-effects models with percent cover of Scotch broom and percent cover of vegetation as fixed effects and plot nested within year as the random effects. Total soil water $\mathrm{N}$ was log-transformed to meet assumptions of normality and homoscedasticity. For soil nutrients, we tested the final estimates of the soil nutrients measured (Table S13), their relative 4-year change [(Nutrient ${ }_{\text {year } 4}-$ Nutrient $\left._{\text {year } 1}\right)$ /Nutri-

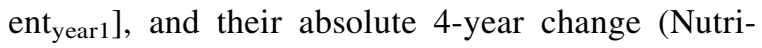
ent $_{\text {year4 }}-$ Nutrient $_{\text {year } 1}$ ) in linear models. Since the soil nutrient response variables were not repeated measures, no random effects were necessary. Independently, Scotch broom crown volume was also tested in these same models as a sole predictor in an attempt to further inform the potential effects of Scotch broom on soil variables on a per-unit-size basis.

\section{Results}

Soil water content

Annual precipitation was 174, 254, 243, and $269 \mathrm{~cm}$ in 2013, 2014, 2015, and 2016, respectively. Precipitation during the growing season (April-September) of those same years was $75,58,33$, and $30 \mathrm{~cm}$, respectively.

In all years, SWC was significantly lower in the presence versus absence of background vegetation (interaction of vegetation $\times$ bi-weekly period 2013: $\mathrm{F}(11,223)=31.0 ; p<0.001$; Table S1; 2014: $\mathrm{F}(13,227)=2.5 ; p=0.003$; Table S2; 2015: $\mathrm{F}$ $(13,279)=3.7 ; p<0.001 ; 2016: \mathrm{F}(12,259)=5.3$; $p<0.001$; Fig. 1). The three-way interaction of Scotch broom, vegetation, and bi-weekly period was marginally significant in 2015 (F (13, $279)=1.7, p=0.06$; Fig. 1 ; Table S3), indicating that the SWC varied differently among the four treatment combinations over time. In 2015, SWC in the Scotch-broom-only treatment was lower than the vegetation-only treatments both earlier and later in the growing season-although these differences were only marginally significant by the end of the growing season-specifically April 3-April 14 (period 1; $\mathrm{t}=-2.7, p=0.03)$, April 15-April 29 (period 2; $\mathrm{t}=-2.6, p=0.05)$, September 3-September 24 (period 12; $\mathrm{t}=-2.35, p=0.09)$, and October 14 October 24 (period 14; $\mathrm{t}=-2.4 ; p=0.08$ ). From May 26 to June 8, the Scotch-broom-only treatment had slightly lower SWC than the bare-ground treatment (period $5 ; \mathrm{t}=2.3 ; p=0.09$ ). From June 9 to July 8 , the Scotch-broom-only (period 6 and 7 ; $\mathrm{t}=3.0 ; p=0.02 ; \mathrm{t}=3.1 ; p=0.01)$, vegetation-only (period 6 and $7 ; \mathrm{t}=4.0 ; \quad p<0.001 ; \mathrm{t}=4.0$; $p<0.001$ ), and Scotch broom-and-background-vegetation (period 6 and $7 ; \mathrm{t}=2.6 ; p=0.04 ; \mathrm{t}=2.5$; $p=0.04$ ) treatments all had significantly lower SWC than the bare-ground treatment. This trend continued for the vegetation-only treatment from July 9 to July 23 (period 8), as it sustained a significantly lower SWC than the bare-ground treatment $(\mathrm{t}=3.0$; $p=0.02)$. In 2016, there was a significant main effect of Scotch broom $(\mathrm{F}(12,259)=7.3 ; p=0.007$; Table S4) and SWC was greater under Scotch broom absence $(\mathrm{t}=2.2 ; p=0.03)$ than Scotch broom presence. 
Fig. 1 Three-way interaction of Scotch broom, vegetation and bi-weekly period predicting least squares means of volumetric soil water content (bars represent $90 \%$ confidence intervals)—means adjusted for the initial 2013 soil water content-over the extent of the experiment. Asterisks denote significant differences $(p<0.1)$ within dates among the treatments; refer to text for detail on which treatment comparisons differ
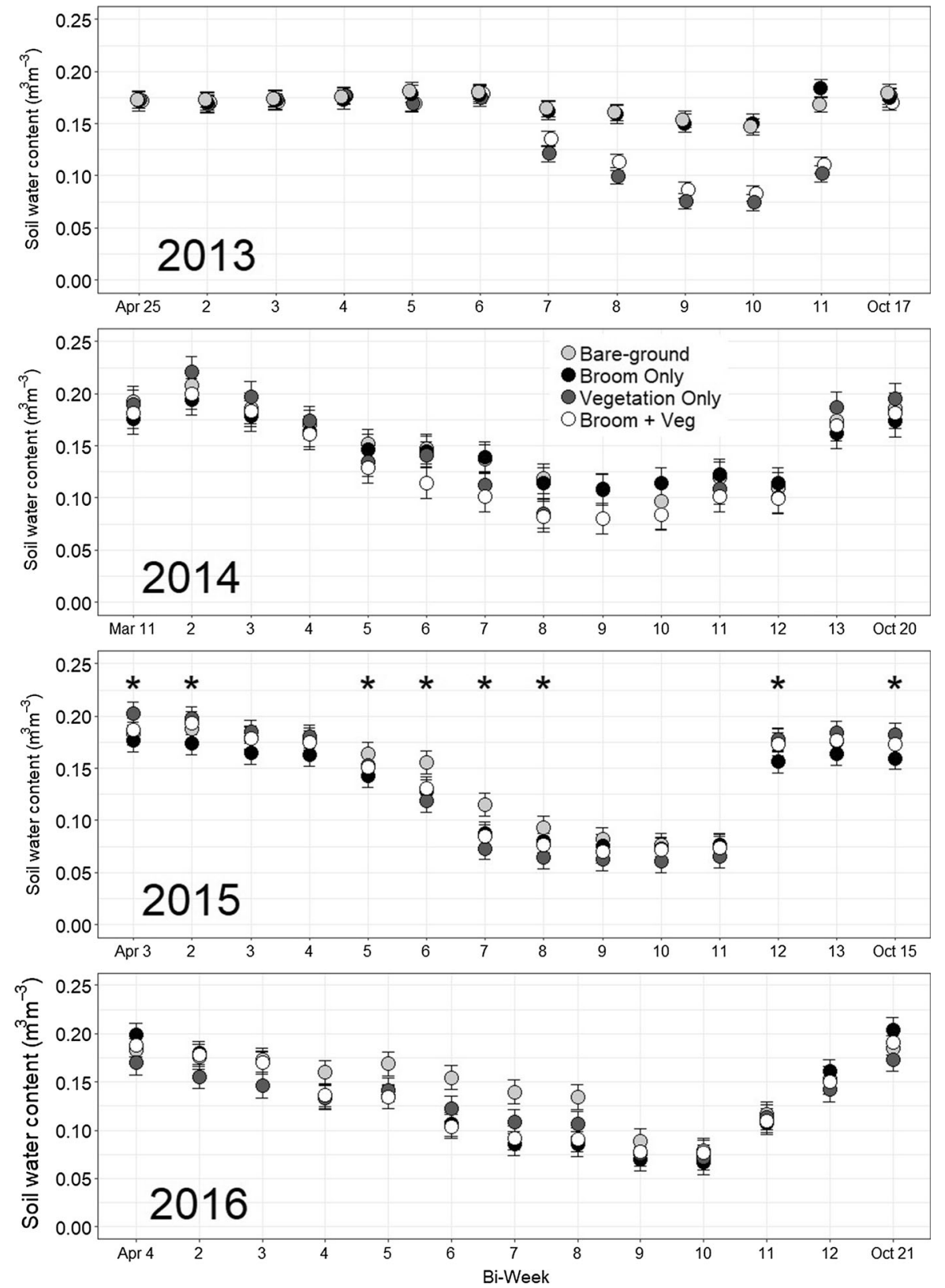

Soil water chemistry

In 2015, the three-way interaction of Scotch broom, vegetation, and season was highly significant in predicting total soil water $\mathrm{N}(\mathrm{F}(1,162)=7.2$; $p=0.008$; Fig. 2; Table S5). There were no differences in total soil water $\mathrm{N}$ among plots in the earlyseason. In the late-season, there was a greater concentration of total soil water $\mathrm{N}$ in the bare-ground treatment than the vegetation-only $(\mathrm{t}=4.9 ; p$ : 0.001$)$ and Scotch broom-and-vegetation $(\mathrm{t}=2.7 ; p=0.04)$ treatments, as well as a greater concentration in the Scotch broom-only treatment than the vegetation-only treatment $(\mathrm{t}=2.7 ; p=0.04)$.

Continuations of these trends were examined in early-2016 (Fig. 2; Table S6). Soil water samples could not be collected reliably in the late-season of 2016; hence, the largest high-order interaction was Scotch broom (presence or absence) and vegetation (presence or absence). There were no significant 
differences among treatments in terms of total soil water $\mathrm{N}$.

In 2015, the two-way Scotch broom and vegetation interaction was the only significant high-order interaction predicting soil water $\mathrm{Ca}[\mathrm{F}(1,162)=15.2$; $p<0.001$; Fig. 2; Table S7]. Ca concentrations were much greater in the Scotch broom-only treatment than in all other treatments (bare-ground: $\mathrm{t}=-6.3$; $p<0.001$; Scotch broom-and-vegetation: $\mathrm{t}=6.0$; $p<0.001$; vegetation-only: $\mathrm{t}=6.0 ; p<0.001$ ).

In 2016, there were significant main effects of Scotch broom $[\mathrm{F}(1,32)=4.9 ; p=0.03]$ and vegetation $[\mathrm{F}(1,32)=25.7 ; p<0.0001$; Table S8] on soil water $\mathrm{Ca}$ concentrations. Scotch broom presence had a greater concentration of $\mathrm{Ca}$ than Scotch broom absence $(\mathrm{t}=-2.5 ; p=0.02)$. Vegetation absence, however, had a greater concentration than vegetation presence $(\mathrm{t}=4.4 ; p<0.001)$.

In 2015, the three-way interaction of Scotch broom, vegetation and season was significant in predicting soil water $\operatorname{Mg}(\mathrm{F}(1,162)=6.9 ; p=0.01$; Fig. 2; Table S9). Early-season Mg concentrations were greater in the Scotch broom-only treatment than in the bare-ground $(\mathrm{t}=-3.9 ; p=0.001)$ and vegetation-only ( $\mathrm{t}=3.3 ; p=0.007)$ treatments. There were no significant differences in $\mathrm{Mg}$ concentrations among the treatments in the late-season.

In 2016, the two-way interaction of Scotch broom and vegetation was significant in predicting soil water $\operatorname{Mg}[\mathrm{F}(1,32)=12 ; p=0.002 ;$ Table S10]. $\mathrm{Mg}$ concentrations in the Scotch broom-only treatment were significantly greater than all other treatments
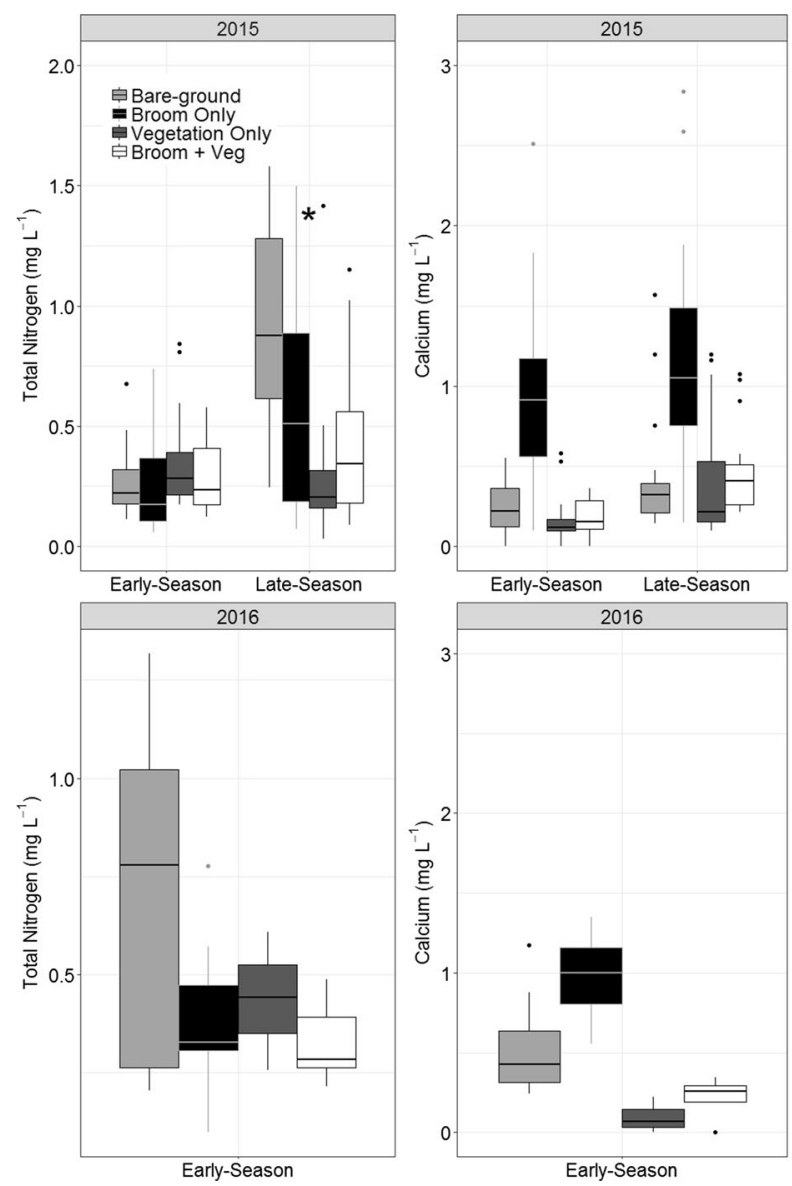

Fig. 2 Three-way interactions of Scotch broom, vegetation, and season predicting soil water nutrient concentrations (total nitrogen and early-season magnesium were back-transformed)-Asterisks denote significant differences. In box-and-
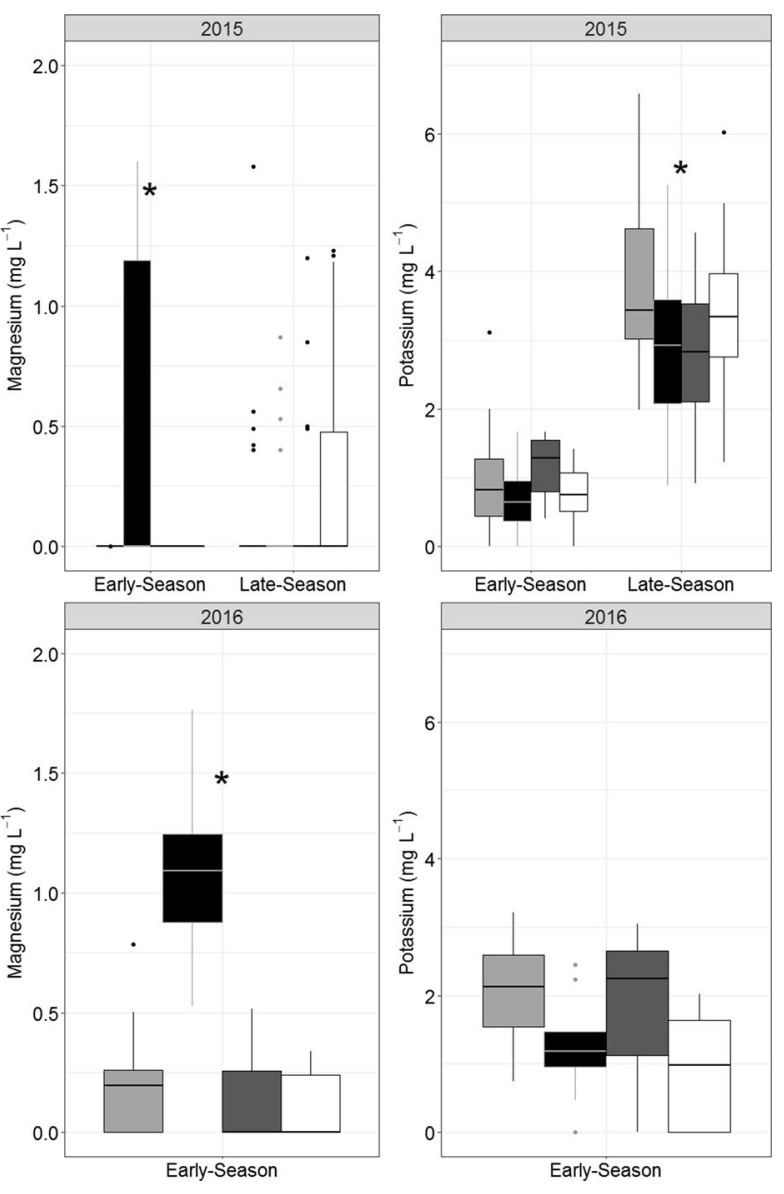

whisker plots, the boxes represent the interquartile range, the median is the vertical line inside the box, and the whiskers are the highest and lowest observation 
(vegetation-only: $\mathrm{t}=3.6 ; p=0.006 ;$ bare-ground: $\mathrm{t}=-6.1 ; p<0.001$; Scotch broom-and-vegetation: $\mathrm{t}=5.6 ; p<0.001)$.

In 2015, the three-way interaction of Scotch broom, vegetation and season was significant in predicting soil water $\mathrm{K}[\mathrm{F}(1,162)=6.4 ; p=0.01$; Fig. 2 ; Table S11]. Early-season concentrations did not differ among treatments. In the late-season, the bare-ground treatment had significantly greater concentrations of $\mathrm{K}$ than the Scotch broom-only $(\mathrm{t}=3.1 ; p=0.01)$ and vegetation-only $(\mathrm{t}=3.2 ; p=0.01)$ treatments.

In 2016, there was a significant main effect of Scotch broom on soil water K concentrations [F (1, $32)=6.1 ; p=0.02 ;$ Table S12]. Scotch broom absence had, to a small degree, a greater concentration of $\mathrm{K}$ than Scotch broom presence $(\mathrm{t}=1.7 ; p=0.09)$.

Concentrations of $\mathrm{PO}^{4+}$ were always below detection limits and are therefore not reported in the results.

\section{Soil nutrients}

Treatment effects on soil chemical properties were limited and only associated with the vegetation factor (Table S13). The 4-year (2013-2016) change in available soil $\mathrm{P}$ was significantly greater $(p=0.02)$ when vegetation was present than when it was absent. The estimated differences between treatments was $1.2 \mathrm{mg} \mathrm{kg}^{-1}( \pm 0.5)$. In contrast, the change in extractable soil $\mathrm{K}$ was substantially lower when vegetation was present compared to when it was absent $(p:<0.001)$, but both vegetation-present and vegetation-absent plots had significant increases over the 4-year period $\left(44 \pm 0.5 \mathrm{mg} \mathrm{kg}^{-1}\right.$ and $11 \pm 0.5 \mathrm{mg} \mathrm{kg}^{-1}$ in the vegetation absent vs. present treatments, respectively). There were no other effects of treatment on any soil chemical property (Table S14).

\section{Soil temperature and $\mathrm{PAR}_{\mathrm{B}}$}

The three-way interaction of Scotch broom, vegetation, and month predicting mean soil temperature was marginally significant in $2015[\mathrm{~F}(11,205)=1.63$; $p=0.09$; Table S15]. No other within-year and response variable (minimum or maximum temperature) combination had a significant three-way interaction. Within-month mean temperatures of the Scotch broom-only treatment $\left(9.78 \pm 0.17^{\circ} \mathrm{C}\right)$ was significantly greater than that of the bare-ground treatment $\left(9.06 \pm 0.47{ }^{\circ} \mathrm{C}\right)$ in April $(\mathrm{t}=-3.2 ; p=0.007)$. For the months of June, July, and August, mean soil temperature in the Scotch broom-only treatment (June: $19.5 \pm 0.52{ }^{\circ} \mathrm{C}$; July: $22 \pm 0.51{ }^{\circ} \mathrm{C}$; August: $20.3 \pm 0.36^{\circ} \mathrm{C}$ ) was significantly greater than that in the bare-ground treatment (June: $18.1 \pm 1.4{ }^{\circ} \mathrm{C}$; $\mathrm{t}=-3.1 ; p=0.01 ;$ July: $20.4 \pm 1.4{ }^{\circ} \mathrm{C} ; \mathrm{t}=-3.2$; $p=0.07 ; \quad$ August: $\quad 18.8 \pm 1.1{ }^{\circ} \mathrm{C} ; \quad \mathrm{t}=-3.1$; $p=0.01$ ), vegetation-only (June: $16.9 \pm 0.7{ }^{\circ} \mathrm{C}$; $\mathrm{t}=4.9 ; \quad p<0.001 ;$ July: $20.2 \pm 0.8{ }^{\circ} \mathrm{C} ; \quad \mathrm{t}=3.6$; $p=0.002 ; \quad$ August: $\quad 18.6 \pm 0.6{ }^{\circ} \mathrm{C} ; \quad \mathrm{t}=2.8$; $p=0.03$ ), and Scotch broom-and-vegetation treatments (June: $17.4 \pm 0.5^{\circ} \mathrm{C} ; \mathrm{t}=4.2 ; p=0.0002$; July: $19.7 \pm 0.6{ }^{\circ} \mathrm{C} ; \mathrm{t}=4.3 ; \quad p<0.001$; August: $\left.18.7 \pm 0.6^{\circ} \mathrm{C} ; \mathrm{t}=2.7 ; p=0.04\right)$.

The two-way interaction of Scotch broom (presence or absence) and year (2015 and 2016) predicting $\mathrm{PAR}_{\mathrm{B}}$ was the only high-order interaction that was significant $[\mathrm{F}(1,472)=8.1 ; p=0.005$; Table S16]. In 2015 , there were no significant differences between Scotch broom presence $(88.8 \pm 1.1 \%)$ and absence $(91 \pm 0.8 \% ; \mathrm{t}=1.4 ; p=0.15)$. In 2016, plots without Scotch broom $(99 \pm 0.5 \%)$ had greater PAR $_{B}$ $(\mathrm{t}=5.4 ; p<0.001)$ values than plots with Scotch broom $(90.4 \pm 1.6 \%)$. The background vegetation term was also significant $[\mathrm{F}(1,472)=9.1 ; p=0.003$; Table S16] with the background-vegetation-absent plots having a greater $\mathrm{PAR}_{\mathrm{B}}$ than the backgroundvegetation-present plots (estimate $=3.4 \pm 1.1$; $\mathrm{t}=3.0 ; p=0.003)$.

\section{Growth}

Mean ( \pm SE) initial height, geometric mean crown width, and crown volume at planting were $117.1 \pm 7.0 \mathrm{~cm}, \quad 54.04 \pm 4.3 \mathrm{~cm}, \quad$ and $0.2 \pm 0.04 \mathrm{~m}^{3}$ and did not vary between treatments $(\mathrm{t}=-1.4 ; \quad p=0.19, \quad \mathrm{t}=-1.04 ; \quad p=0.32$, and $\mathrm{t}=-1.1 ; p=0.29)$. The overall trend among the three growth metrics during the study was that isolated Scotch broom grew more than those growing with background vegetation, although the difference was not statistically significant (Fig. 3).

The two-way interaction of treatment and measurement predicting height was not significant [F (4, 74) $=1.47 ; p=0.22$; Fig. 3; Table S17], nor was the main effect of treatment $[\mathrm{F}(1,74)=0.3 ; p=0.58]$. However, significant differences between treatments were present for the other growth metrics. 
The two-way interaction of treatment and measurement predicting geometric mean crown width was significant $[\mathrm{F}(4,74)=2.62 ; p=0.04 ;$ Fig. 3 ; Table S18]. The Scotch-broom-and-background-vegetation treatment (back-transformed median \pm SE; $75.0 \pm 6.6 \mathrm{~cm}$ ) had greater geometric mean crown width than the Scotch-broom-only treatment $(58.4 \pm 9.0 \mathrm{~cm})$ in the second measurement, January, $2014(\mathrm{t}=2.5 ; p=0.01$; Fig. 3$)$, no other withinmeasurement comparisons were significant (measurement $1: \quad \mathrm{t}=-0.16 ; p=0.88 ;$ measurement 3 : $\mathrm{t}=0.28 ; \quad p=0.78 ;$ measurement $4: \quad \mathrm{t}=-0.53$; $p=0.6$; measurement $5: \mathrm{t}=-1.0 ; p=0.3$ ).

The two-way interaction of treatment and measurement predicting crown volume was significant $[\mathrm{F}(4$, 74) $=2.82 ; p=0.03$; Fig. 3 ; Table S19]. The Scotchbroom-and-background-vegetation treatment $\left(0.32 \pm 0.05 \mathrm{~m}^{3}\right)$ had a greater canopy volume than the Scotch broom-only treatment $\left(0.26 \pm 0.08 \mathrm{~m}^{3}\right)$ in
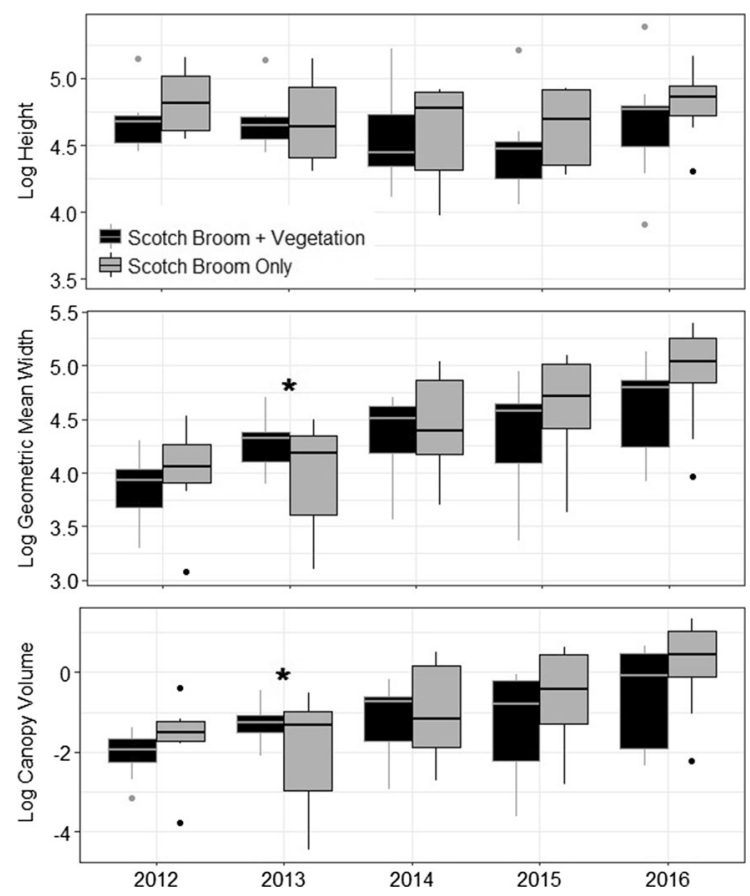

Fig. 3 Comparisons in growth measurements over the five measurements between the Scotch broom-and-back-groundvegetation treatment and the Scotch broom-only treatment. $\mathrm{X}$-axis labels indicate end-of-year values ("2012" = immediately after planting). Asterisks denote significant differences $(p<0.1)$ within seasons among the treatments. In box-andwhisker plots, the boxes represent the interquartile range, the median is the vertical line inside the box, and the whiskers are the highest and lowest observation the second measurement, January, $2014(\mathrm{t}=2.78$; $p=0.007$ ), no other within-measurement comparisons were significant (measurement $1: \mathrm{t}=-0.04$; $p=0.97$; measurement $3: \mathrm{t}=0.65 ; p=0.52$; measurement $4: \mathrm{t}=-0.38 ; p=0.71 ;$ measurement 5 : $\mathrm{t}=0.78 ; p=0.45)$.

\section{Vegetation communities}

Percent cover data from bare-ground plots showed that the vegetation control treatments were effective over the duration of the study (2014: $0.8 \pm 0.2 \%$; 2015: $1.2 \pm 0.2 \% ; 2016: 1.0 \pm 0.2 \%)$. Over the 3 -year period (2014-2016) vegetation communities were measured, a total of 56 species were identified. The most dramatic changes in average percent cover of these species among the vegetation-only plots were increases in Saskatoon serviceberry; $4.5 \pm 2.9 \%$, Hypochaeris radicata L. (hairy cat's ear; $13.3 \pm 2.5 \%)$ and Symphoricarpos hesperius G. $\mathrm{N}$. Jones (trailing snowberry; $5.1 \pm 1.4 \%$ ) and decreases in sweet vernalgrass $(-7.2 \pm 5 \%)$ and Bromus vulgaris (Hook.) Shear (Columbia brome; $-4.4 \pm 4.4 \%)$. In the Scotch broom-and-vegetation plots, the most dramatic changes were increases in sweet vernalgrass $(11.8 \pm 3.9 \%)$ and hairy cat's ear $(5.5 \pm 2 \%)$.

The two-way interaction of treatment (vegetationonly and Scotch broom-and-vegetation) and year in the multivariate ANOVA predicting $\beta$-diversity dissimilarities among treatments over time based on species relative abundances was significant [F (1, 56) $=2.44 ; p=0.02$; Table S20]. This indicates that species assemblages differed among treatments over time.

The two-way interactions of treatment and year varied some what in significance in predicting the three biodiversity response variables [the Simpson index $[\mathrm{F}(2,54)=3.02 ; p=0.06$; Table S21], the Shannon index $[\mathrm{F} \quad(2,54)=4.04 ; p=0.02$; Table S22], and richness $[\mathrm{F}(2,54)=3.6 ; p=0.04$; Table S23]]. The Simpson $(0.75 \pm 0.02$ to $0.8 \pm 0.02 ; \quad \mathrm{t}=2.5 ; \quad p=0.04), \quad$ Shannon $(1.69 \pm 0.08$ to $1.93 \pm 0.08 ; \mathrm{t}=2.8 ; p=0.02)$, and richness $(7.9 \pm 0.4$ to $9.4 \pm 0.43 ; \mathrm{t}=2.3 ; p=0.06$ ) indices in the background vegetation-only treatment significantly increased from 2014 to 2016 (Fig. 4). These same indices declined, although not significantly, in the Scotch broom-and-vegetation treatment 
from 2014 to 2016 (Fig. 4; Simpson: $0.79 \pm 0.02$ to $0.77 \pm 0.02 ; \mathrm{t}=0.9 ; p=0.62$; Shannon: $1.9 \pm 0.07$ to $1.79 \pm 0.07 ; \quad \mathrm{t}=1.2 ; \quad p=0.48 ; \quad$ richness: $9.2 \pm 0.61$ to $8.4 \pm 0.5 ; \mathrm{t}=1.2 ; p=0.44)$.

$T$ tests comparing the absolute changes in the percent cover of native and nonnative species from 2014 to 2016 between treatments showed no significant change in the presence of natives $(\mathrm{t}=1.37$; $p=0.19 ; \quad$ vegetation-only: $0.6 \pm 3.8 \%$; Scotch broom-and-vegetation: $-7.2 \pm 4.3 \%$ ). However, there was a marginal increase in nonnative species in the Scotch broom-and-vegetation $(16.4 \pm 4.7 \%)$ treatment relative to the vegetation-only treatment $(6.9 \pm 3.3 \% ; \mathrm{t}=-1.65 ; p=0.11)$.

The two-way interaction of treatment and growth form was highly significant $[\mathrm{F}(7,144)=3.07$; $p=0.005$; Table S24] in predicting percent cover change. The absolute change in percent cover in nonnative grasses and total (native and nonnative) grasses in the Scotch broom-and-vegetation plots $(9.9 \pm 3.7 \% ; 7.0 \pm 3.5 \%)$ were significantly greater $(\mathrm{t}=-3.0 ; p=0.003$ and $\mathrm{t}=-2.85 ; p=0.005$, respectively) than those in the vegetation-only plots $(-7.9 \pm 3.9 \%$; $-9.2 \pm 6.1 \%$; Fig. 5). These relationships remained after the high leverage point in the total grass percent cover was removed $[\mathrm{F}$ (7, 143) $=3.06 ; p=0.005 ; \mathrm{t}=-2.04 ; p=0.04]$. No nonnative sedges or woody perennials were found in the plots; therefore, the totals shown in Fig. 5 represent native species only. Supplementary Table S26 shows the full list of species sampled in this study and their absolute percent change in cover from 2014 to 2016.

Relating percent cover to soil measurements

Canopy volume of Scotch broom and percent cover were strongly correlated (Adjusted $\mathrm{R}^{2}=0.69$; $\beta=0.03 ; \mathrm{t}=12.2 ; p<0.001)$. For approximately every $0.03 \mathrm{~m}^{3}$ increase in canopy volume we saw $1 \%$ increases in canopy cover estimates. The mean canopy volume over the years that coincided with percent cover vegetation surveys were $0.41 \pm 0.06$ in 2014 , $0.67 \pm 0.14$ in 2015 , and $1.37 \pm 0.28$ in 2016 .

$$
\begin{array}{ccc}
\text { Percent } \quad \text { cover } & \text { of } \quad \text { vegetation } \\
(\beta=-0.00006 \pm 0.00003 ; & \mathrm{t}=-2.2 ; & p=0.03)
\end{array}
$$
and percent cover of Scotch broom $(\beta=-0.0004 \pm 0.0002 ; \mathrm{t}=-2.5 ; p=0.02)$ were both negatively correlated with SWC. Scotch broom had a more dramatic negative influence on SWC per unit of cover than did vegetation. Scotch broom crown volume also showed a significant negative correlation with SWC $\quad(\beta=-0.01 \pm 0.005 ; \quad \mathrm{t}=-2.3$; $p=0.03$ ), which agrees with the previous finding.

Percent cover of vegetation was highly negatively correlated with total $\mathrm{N} \quad(\beta=-0.002 \pm 0.001$; $\mathrm{t}=-3.0 ; p=0.004), \operatorname{Mg}(\beta=-0.002 \pm 0.001$; $\mathrm{t}=-2.8 ; p=0.01)$, and $\mathrm{Ca}(\beta=-0.002 \pm 0.001$; $\mathrm{t}=-2.4 ; p=0.02)$ in the soil water, while Scotch broom percent cover was only marginally negatively correlated with soil water $\mathrm{K}(\beta=-0.001 \pm 0.001$; $\mathrm{t}=-1.7 ; p=0.09)$. Scotch broom canopy volume was not significant in predicting any of the soil water cation estimates.

Percent cover of vegetation in 2016 was strongly associated with changes in $\mathrm{K}$ and $\mathrm{P}$ in the soil. Neither percent cover nor canopy volume of Scotch broom were correlated with any changes in soil nutrients. Final soil $\mathrm{K}$ estimates $(\beta=0.15 \pm 0.04 ; \mathrm{t}=3.8$; $p=0.001)$, absolute 4-year changes in $\mathrm{K}$ $(\beta=0.24 \pm 0.06 ; \mathrm{t}=4.0 ; p<0.001)$, and relative 4-year changes in $\mathrm{K}(\beta=0.002 \pm 0.001 ; \mathrm{t}=3.6$; $p=0.002$ ) were all positively correlated with the vegetation cover in 2016. Similarly, absolute $(\beta=-0.01 \pm 0.004 ; \mathrm{t}=-2.7 ; p=0.01)$ and relative changes $(\beta=-0.001 \pm 0.0004 ; \mathrm{t}=-3.5$; $p=0.002$ ) in $\mathrm{P}$ over the 4-year period were negatively correlated with vegetation cover in 2016.

\section{Discussion}

Using an addition experiment, we were able to demonstrate multiple effects of Scotch broom presence on the local environment and vegetation. Scotch broom, relative to background vegetation plots, was associated with reductions in SWC early and, less so, late in the growing season, increases in soil water $\mathrm{Ca}^{2+}$ and $\mathrm{Mg}^{2+}$, reduced PAR, and an increased cover of nonnative grass. Taken together, these effects indicate potential for multiple mechanisms by which Scotch broom may alter the microenvironment relative to that found under background vegetation.

Our hypothesis regarding an increased utilization of soil water compared to background vegetation was partially substantiated by the statistical comparisons. There was some supporting evidence in the general trends in SWC among treatments. While background 
Fig. 4 Changes in the Simpson, Shannon-Wiener, and richness indices over 3 years (2014-2016) between the backgroundvegetation treatment and the Scotch-broom-andbackground-vegetation treatment. Bars represent the $90 \%$ confidence intervals. Asterisks denote significant differences $(p<0.1)$ within years between treatments. Refer to the text for statistical comparisons within treatments among years
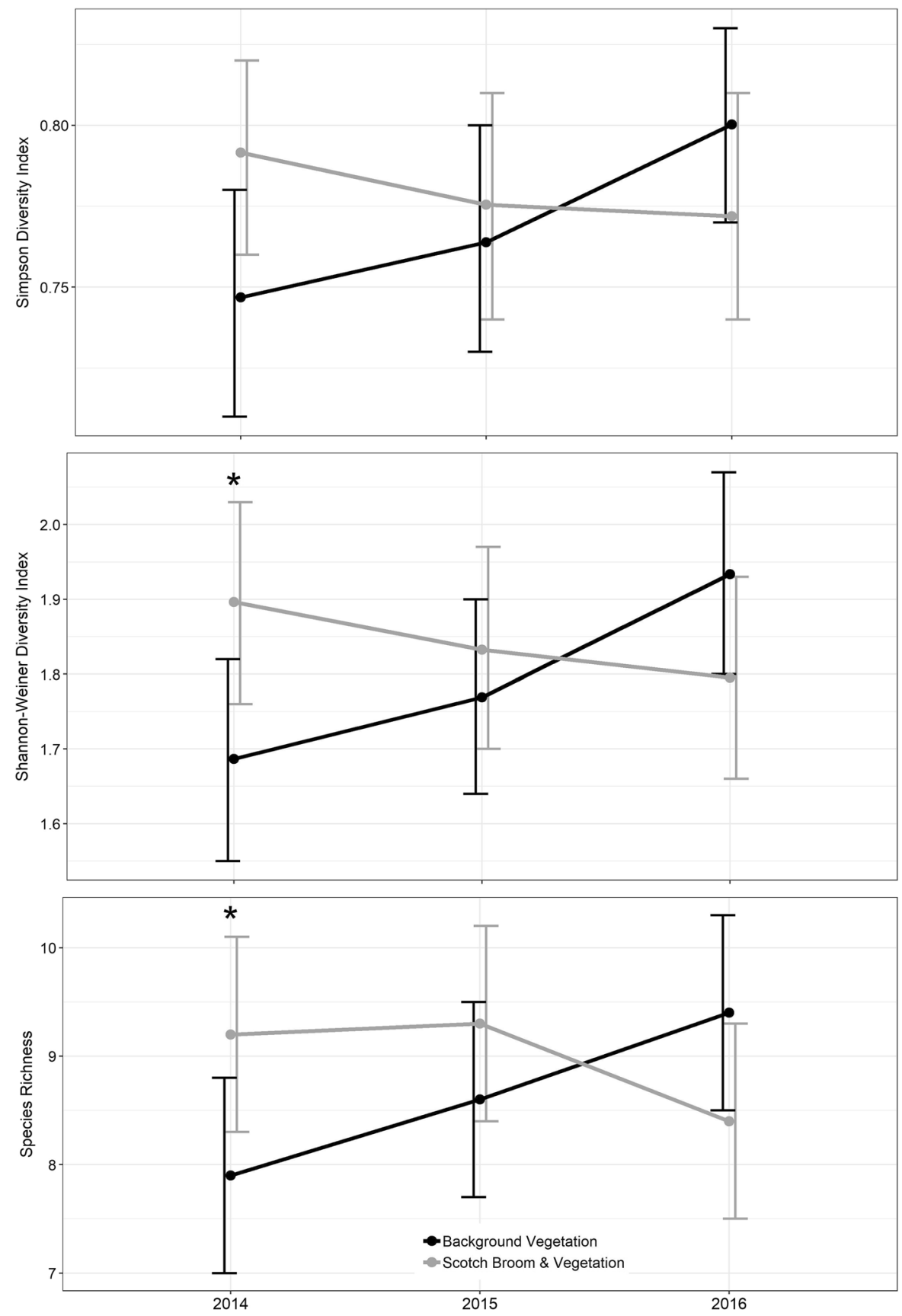

vegetation clearly had the greatest influence on SWC (readily apparent in 2013), beginning in 2014 and for the remaining duration of the study, SWC in Scotchbroom-only plots was depleted similarly to that observed for vegetation-only and Scotch-broom-andvegetation plots. These three treatments had significantly lower SWC than the bare-ground treatment from June 9 to July 8 (periods 6 and 7) in 2015. This indicates that, during this period, plots with only a single Scotch broom plant present had as much soil water usage as those that were fully vegetated. This trend was, in part, continued into 2016 as the plots with Scotch broom present had lower SWC than plots without Scotch broom. Vegetation, however, 


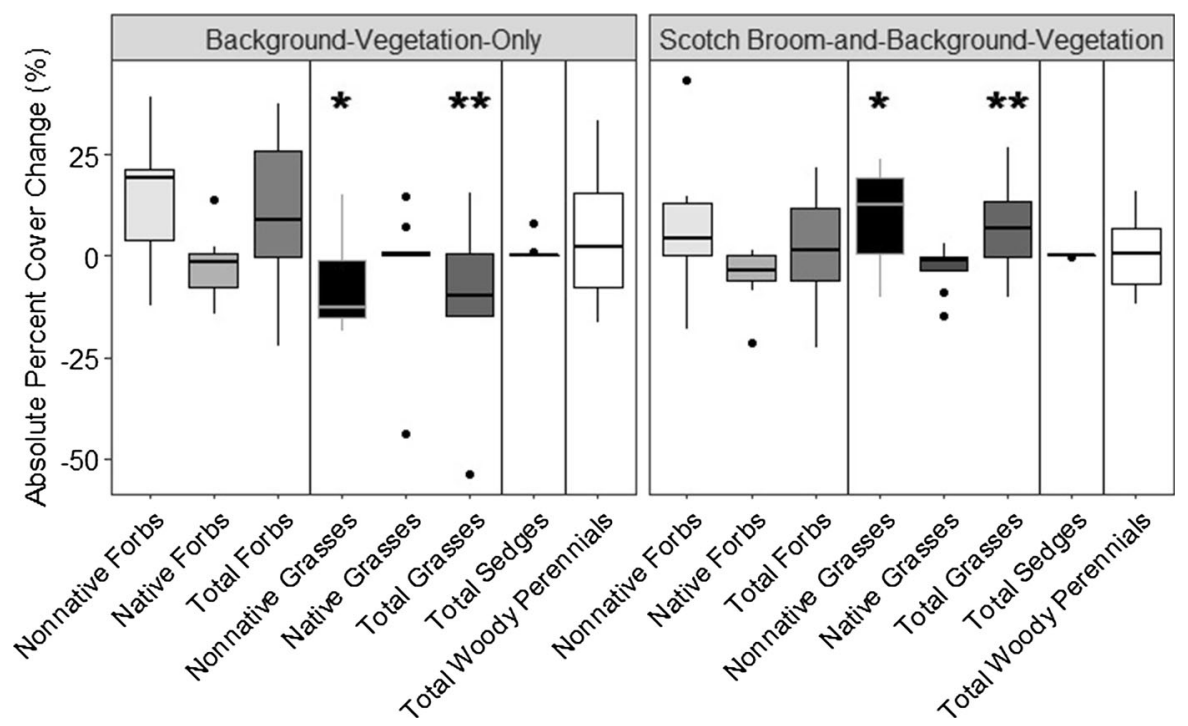

Fig. 5 Differences in absolute percent cover change from 2014 to 2016 of nonnative and native growth forms between the vegetation-only and the Scotch broom-and-vegetation plots (vertical lines delineate growth forms within-treatment and asterisks of the same quantity denote differences between

remained the more influential predictor throughout 2016.

Scotch broom plants growing larger over the course of the experiment, coupled with more intense drought periods, likely accounted for their influence on the SWC in 2015 and 2016, relative to 2013 and 2014. The larger crowns of Scotch broom would have contributed to greater depletion as a result of relatively high ET (Boldrin et al. 2017), especially given the increased SWC usage per unit of Scotch broom cover. On a percent cover basis, Scotch broom had a highly disproportionate effect on SWC relative to background-vegetation. This is at least in part driven by the greater accumulation of vertical biomass relative to the background vegetation which is simplified in a percent cover estimate. This finding supports our expectation that Scotch broom has greater soil water usage than background vegetation. As with the other measurements of isolated Scotch broom plants in this study, if this finding were extrapolated to reflect a thicket of Scotch broom, this increased usage of soil water would likely be marked at the site-level.

In 2015, our results showed significantly lower SWC under Scotch broom than the other treatments both earlier and, to a lesser degree, later in the growing season and, although not significant, this trend was treatments within-group). In box-and-whisker plots, the boxes represent the interquartile range, the median is the vertical line inside the box, and the whiskers are the highest and lowest observation

also seen in 2014. Scotch broom maintained high soil water usage until early July, 2015. After early July, 2015, the soil water usage in the Scotch broom-only plots began to equal that of the bare-ground plots. This pattern of soil water usage may be due to Scotch broom's drought-deciduous phenology (Matías et al. 2012; Boldrin et al. 2017) and subsequently lowered water demands during the peak of the summer drought. Scotch broom may be taking advantage of the high soil water availability during other parts of the year to accrue its biomass, as it can photosynthesize in temperatures as low as $4{ }^{\circ} \mathrm{C}$ (Wheeler et al. 1979). This preemption of soil water use and extended growing season may be influencing the vegetation community by reducing soil moisture requirements for growth and germination of certain species at critical times of development. Research is needed to investigate the effects of Scotch broom on soil moisture in the top layer of soil during the early part of the growing season and its relationship with germination of associated species.

We expect that some experimental design artifacts may have influenced soil water usage measurements. Firstly, the deep rooting habit of Scotch broom (Allen and Allen 1981), may have enabled it to access soil water below the $30 \mathrm{~cm}$ depth of the soil moisture 
sensor, which would have resulted in an underestimate of soil water usage by this plant. Secondly, the bareground and Scotch broom-only plots were kept clear of vegetation; however, there was no attempt made to occlude adjacent roots from entering the plots in any of the treatments. The effect of adjacent roots is likely because the differences in SWC between vegetated and non-vegetated became less over time (Fig. 1). This could be due to the proliferation of existing lateral roots adjacent to the plot in the absence of competition in the non-vegetated plots. The presence of vegetation most strongly influenced SWC in the analyses, however, which indicates that non-vegetated plots were less occupied by roots than the vegetated plots. Similarly, droughts became more severe in 2015 and 2016 and, despite this, Scotch broom consistently showed soil water usage during the peak of the drought that was comparable to the high soil water usage of the background-vegetation. The percent cover estimate of plant size was tightly correlated with the crown volume of Scotch broom, however, periodic harvests of Scotch broom and vegetation to estimate aboveground biomasses would provide a better comparison of soil water usage on a per gram basis.

Our hypothesis that Scotch broom would increase soil water cations and soil nutrients was only partially supported by our results. The soil water cation concentrations were highly variable, particularly with $\mathrm{K}^{+}$. The concentration of soil water $\mathrm{K}^{+}$was lower in the background-vegetation and the Scotch-broom only treatments than the bare-ground plot in 2015. In 2016, soil water $\mathrm{K}^{+}$was marginally greater in plots without Scotch broom than those with Scotch broom. The percent cover analysis revealed that as Scotch broom grew larger, significantly less $\mathrm{K}^{+}$was found in the soil water. This may indicate a unique nutrient demand of this species. We also consistently found increases in the soil water $\mathrm{Mg}^{2+}$ and $\mathrm{Ca}^{2+}$ concentrations associated with Scotch broom, however. The greater concentrations of $\mathrm{Mg}^{2+}$ and $\mathrm{Ca}^{2+}$ indicate these nutrients are in greater flux, either from being displaced from the exchange complex by $\mathrm{N}$-fixed $\mathrm{NH}^{4+}$ or from increased mineral weathering under Scotch broom in isolation. Increased soil water $\mathrm{Mg}^{2+}$ and $\mathrm{Ca}^{2+}$ in the presence of Scotch broom could result in depletion of these nutrients given that the tension lysimeters were intended to be placed at a depth within the rooting zone of Scotch broom and likely reflect a net loss from soil. If this trend were to be consistent under a thicket of Scotch broom, characteristically devoid of background vegetation when it dominates a site (Paynter et al. 2003), the effect on nutrient pools could be substantial. However, given the long-term results of Slesak et al. (2016), this does not seem likely on these soil types. Finally, it is known that glyphosate application can potentially impede uptake of divalent cations via chelation (Mertens et al. 2018), but we do not think this influenced our findings as higher concentrations of $\mathrm{Mg}^{2+}$ and $\mathrm{Ca}^{2+}$ were only observed in the Scotch broom-only treatment and not the bareground treatment which was also subjected to herbicide application.

We did not consistently find greater total soil water $\mathrm{N}$ in the presence of Scotch broom. In 2015, lateseason measurements of total soil water $\mathrm{N}$ was greatest in the bare-ground treatment, followed by the Scotch broom-only, the Scotch broom-and-background-vegetation, and the background-vegetation treatments. In 2016, there were no significant differences in total soil water $\mathrm{N}$ among treatments, but the total soil water $\mathrm{N}$ in the bare-ground treatment was greater than the other treatments. Supporting this, Slesak et al. (2009) showed that ambient total $\mathrm{N}$ is readily leached where ample vegetation is not present to utilize it. Note that some $\mathrm{N}$ is added as herbicide and may have contributed to the increased soil water $\mathrm{N}$ in those treatments, but total amounts added over the course of the study were very low ( $\sim 0.6 \mathrm{~kg} \mathrm{~N} \mathrm{ha}^{-1}$ year $^{-1}$ ) relative to total soil pools and similar to atmospheric inputs, so any associated artifact is likely small.

Changes in soil nutrient pools were primarily driven by the presence or absence of vegetation. The change in soil extractable $\mathrm{K}$ was lower in the presence of vegetation compared to its absence, while conversely the change in soil extractable $\mathrm{P}$ was higher in the presence of vegetation. Both of these nutrient pools increased over the 4-year duration of the study, however. In earlier work at a nearby site with similar soils, Slesak et al. (2016) also found limited effects of Scotch broom presence on soil chemical properties 10 years after Scotch broom invasion. The changes in soil water chemistry associated with Scotch broom and no concurrent change in soil pools can likely be attributed to the young and coarse-textured soils at these sites, which generally have greater potential for leaching, reduced ability to retain available nutrients (e.g., low OM and CEC), and have high amounts of unweathered primary and secondary minerals. 
Given the relatively large size of the Scotch broom plants in this study, we presume Bradyrhizobium bacteria in Scotch broom root nodules were fixing $\mathrm{N}$. The low concentration of total soil water $\mathrm{N}$ and $\mathrm{N}$ content of the soils findings, however, indicate that Scotch broom is sequestering the fixed-N and effectively translocating and resorbing foliar $\mathrm{N}$ prior to leaf-fall. Grove et al. (2015) had a similar finding in an invaded grassland system where chemical control of Scotch broom generated a short-lived pulse of $\mathrm{N}$ that was greater than the available $\mathrm{N}$ in sites where Scotch broom was alive and intact.

The results from the effects of percent cover of Scotch broom and vegetation on soil water cations and soil nutrients indicated a potentially unique set of nutrient demands of Scotch broom. The negative relationship of percent cover of background vegetation and soil water cations is likely the result of the background vegetation's greater and more diverse nutrient demands and capture in these systems relative to the more coarsely rooted Scotch broom. As Scotch broom grew larger, significantly less $\mathrm{K}^{+}$was found in the soil water relative to that found under the background vegetation. This may indicate a unique nutrient demand of Scotch broom. This potentially high demand for $\mathrm{K}^{+}$found here along with the greater $\mathrm{P}$ demands of Scotch broom (Caldwell 2006; Slesak et al. 2016) may explain the relatively greater abundance of these nutrients on a percent cover basis under the background vegetation in the soil.

Our prediction that Scotch broom would result in lower soil temperatures and lower PAR was only partially substantiated by the results. Average soil temperature was somewhat greater under Scotch broom and $\mathrm{PAR}_{\mathrm{B}}$ was lower, as expected, under Scotch broom. One plausible mechanism leading to the greater average soil temperature in the Scotchbroom only treatment is that without a ground layer of vegetation to shield the soil from solar irradiance (PAR readings were taken at a height of $0.5 \mathrm{~m}$ ) and the lower SWC relative to the bare-ground treatment, the resulting soil temperature was greater. The temperatures on fully vegetated plots were likely moderated by the presence of the background vegetation. Likewise, the presence of the Scotch broom canopy may have increased the boundary layer resistance, trapping warm air, unlike the bare-ground treatment which likely quickly heated and re-radiated this heat. The lower $\mathrm{PAR}_{\mathrm{B}}$ under Scotch broom in 2016 may reflect the greater height and associated shade of the Scotch broom canopy relative to other vegetation colonizing these sites. Interestingly, there was no effect of Scotch broom's canopy in 2015. This appears to be an effect of the background vegetation having grown to a height that affected the $\mathrm{PAR}_{\mathrm{B}}$ in the absence of Scotch broom. This is surprising given that 2015 was a harsher year than 2016, with respect to the drought, and some dieback among background vegetation and the planted Scotch broom was apparent.

Our data demonstrate that Scotch broom is not inhibited by the presence of competing vegetation. While the Scotch broom grown without competing vegetation did grow generally larger than the Scotch broom grown among background vegetation, these differences were not significant. This finding implies that Scotch broom may be acquiring soil water either at a different time of the growing season or from a depth below that of the background vegetation, allowing it to grow despite the presence of other vegetation. Fogarty and Facelli (1999) found that Scotch broom had its highest relative growth rates $\left(\mathrm{mg} \mathrm{g}^{-1} \mathrm{day}^{-1}\right)$ in the spring and autumn, and a negative relative growth rate during the summer. Bossard and Rejmanek (1992) hypothesized that Scotch broom owes its phenological flexibility and extended growing season to its photosynthetic stems which allow it to maintain a net positive carbon balance throughout the year; presumably to maintain its symbiosis with rhizobia.

The study provided clear evidence that Scotch broom increased nonnative plant species cover. Specifically, the results showed Scotch broom presence to be commonly associated with an increase in the percent cover of nonnative grasses sweet vernalgrass. Grasses are known to co-occur with Scotch broom. Shaben and Myers (2009) similarly found the presence of Scotch broom to be associated with increases in exotic grass cover and a decrease in native plant cover. The mechanism by which this phenomenon occurs was posited by Grove et al. (2015) to be a fertilization effect of Scotch broom facilitating the establishment of nitrophyllic nonnative grasses and forbs. Additionally, the changes in composition may also be due to allelopathic effects of Scotch broom disrupting mycorrhizal associations with native plant species (Grove et al. 2012).

While Scotch broom was often associated with nonnative grasses, Scotch broom-absent plots were 
seemingly more resistant to invasion by nonnative species and harbored more diversity. The Simpson and Shannon diversity indices and species richness slightly increased over time in the background-vegetationonly treatment, while remaining unchanged or slightly decreasing in the Scotch broom-and-vegetation treatment. Parker et al. (1997) also found the presence of Scotch broom to be associated with decreases in native species richness.

Untested and possible mechanisms accounting for the coexistence of nonnative grass species and the decline of broadleaved species under Scotch broom is the possible partitioning of belowground resources. Of particular interest would be examinations of the rooting strategy of sweet vernalgrass and how, if at all, this strategy facilitates its co-occurrence with Scotch broom. Similarly, the root structures of broadleaved species that declined in cover during the experiment are likely much more similar to that of Scotch broom, while the roots of sweet vernalgrass are more fibrous. Sweet vernalgrass, being a cool-season grass, may also be capable of taking advantage of periods when leaf area is lower on a plot.

\section{Conclusion}

The presence of Scotch broom caused deviations from baseline microenvironment conditions for most of the variables measured. From 2014 to 2016, though not consistently significant, the Scotch-broom only treatment approached a level of soil water usage comparable to that of the fully vegetated plots, demonstrating that Scotch broom is capable of depleting the soil water resource with the same magnitude as background vegetation. This high soil water usage finding was supported in our analysis of SWC on a percent cover basis, where Scotch broom had a greater negative influence on SWC than did background vegetation per unit of percent cover. The presence of Scotch broom was also associated with greater soil water usage earlier and, to a lesser degree, later in the season than background vegetation in 2015. This suggests Scotch broom may use its drought-deciduous phenology to reduce its transpiration during the peak of the drought - to a point that did not differ significantly from the bare-ground treatment in terms of SWC by the end of August. Soil nutrient flux was altered, with increases in soil water cations $\mathrm{Mg}^{2+}$ and
$\mathrm{Ca}^{2+}$ under Scotch broom-only, which may influence nutrient cycling over time. The percent cover analysis indicated Scotch broom may have a uniquely high demand for $\mathrm{K}^{+}$relative to the vegetation found on this site. Scotch broom was also associated with a reduction in $\mathrm{PAR}_{\mathrm{B}}$ and marginally greater soil temperature relative to other treatments, which could influence the germination and development of co-occurring species. Though Scotch broom growth was expected to be lower when competing background vegetation was present, there was no significant effect demonstrating this, providing evidence that Scotch broom is able to acquire resources for growth even when competition is high. The changes in microsite conditions caused by Scotch broom may have prevented the increases in broadleaved species, like trailing snowberry and Saskatoon serviceberry, seen in the background-vegetation plots. The background-vegetation-only treatment showed increasing values in species diversity and richness over time, while the species diversity and richness in the Scotch broom-and-background-vegetation treatment stayed the same. The Scotch broom and background-vegetation treatment also had a significant increase in abundance of nonnative grass compared to the background-vegetation-only treatment. This demonstrates that Scotch broom may facilitate nonnative grass invasion. These compositional shifts may cause additional changes to resource availability and plant community structure in these systems that create significant challenges to establishing and restoring forest vegetation to these areas.

Acknowledgements Financial support for this research was provided by the USDA National Institute for Food and Agriculture (Grants.gov number: GRANT 11325729). We wish to thank Green Diamond Resource Company for use of their land and logistical support. We would like to thank James Dollins for all of his efforts on this project.

\section{References}

Allen ON, Allen EK (1981) The Leguminosae. MacMillan, London

Allison SD, Vitousek PM (2004) Rapid nutrient cycling in leaf litter from invasive plants in Hawai'i. Oecologia 141:612-619

Bannister P (1986) Observations on water potential and drought resistance of trees and shrubs after a period of summer drought around Dunedin, New Zealand. NZ J Bot 24:387-392 
Beatty SW, Sholes OD (1988) Leaf litter effect on plant species composition of deciduous forest treefall pits. Can J For Res 18:553-559

Boldrin D, Leung AK, Bengough AG (2017) Correlating hydrologic reinforcement of vegetated soil with plant traits during establishment of woody perennials. Plant Soil 416:437-451

Bossard CC, Rejmanek M (1992) Why have green stems? Funct Ecol 6:197-205

Bossard CC, Rejmanek M (1994) Herbivory, growth, seed production, and resprouting of an exotic invasive shrub. Biol Conserv 67:193-200

Broadbent AAD, Orwin KH, Peltzer DA, Dickie IA, Mason NWH, Ostle NJ, Stevens CJ (2017) Invasive N-fixer impacts on litter decomposition driven by changes to soil properties not litter quality. Ecosystems 20:1151-1163

Brubaker LB (1980) Spatial patterns of tree growth anomalies in the Pacific Northwest. Ecology 61:798-807

Busse MD, Ratcliff AW, Shestak CJ, Powers RF (2001) Glyphosate toxicity and the effects of long-term vegetation control on soil microbial communities. Soil Biol Biochem 33(12-13):1777-1789

Caldwell BA (2006) Effects of invasive scotch broom on soil properties in a Pacific coastal prairie soil. Appl Soil Ecol 32:149-152

Crews TE (1993) Phosphorus regulation of nitrogen fixation in a traditional Mexican agroecosystem. Biogeochemistry 21:141-166

Dassonwille N, Vanderhoven S, Vanparys V, Hayez M, Gruber W, Meerts P (2008) Impacts of alien invasive plants on soil nutrients are correlated with initial site conditions in NW Europe. Oecologia 133:206-214

Ehrenfeld JG (2003) Effects of exotic plant invasions on soil nutrient cycling processes. Ecosystems 6:503-523

Ehrenfeld JG, Kourtev P, Huang W (2001) Changes in soil functions following invasions of exotic understory plants in deciduous forests. Ecol Appl 11:1287-1300

Fogarty G, Facelli JM (1999) Growth and competition of Cytisus scoparius, an invasive shrub, and Australian native shrubs. Plant Ecol 144:27-35

Grove S, Haubensak KA, Parker IM (2012) Direct and indirect effects of allelopathy in the soil legacy of an exotic plant invasion. Plant Ecol 213:1869-1882

Grove S, Parker IM, Haubensak KA (2015) Persistence of a soil legacy following removal of nitrogen fixing invader. Biol Invasions 17:2621-2631

Hardy RWF, Havelka UD (1976) Photosynthate as a major factor limiting nitrogen fixation by field-grown legumes with emphasis on soybeans. In: Numan PS (ed) Symbiotic nitrogen fixation in plants. Cambridge University Press, Cambridge, pp 421-439

Harrington TB (2011) Quantifying competitive ability of perennial grasses to inhibit Scotch broom. Research Paper PNW-RP-587. U.S. Department of Agriculture, Forest Service, Washington

Harrington TB, Schoenholtz SH (2010) Effects of logging debris on five-year development of competing vegetation and planted Douglas-fir. Can J For Res 40:500-510. https:// doi.org/10.1139/X10-001

Haubensak KA, Parker IM (2004) Soil changes accompanying invasion of the exotic shrub Cytisus scoparius in glacial outwash prairies in Western Washington [USA]. Plant Ecol 175:71-79

Henderson JA, Peter DH, Lesher RD, Shaw DC (1989) Forested plant associations of the Olympic National Forest. R6ECOL-TP 001-88, U. S. Department of Agriculture, Forest Service, Pacific Northwest Region, Portland

Knapp AK, Seastedt TR (1986) Detritus accumulation limits the productivity of tallgrass prairie. Bioscience 36:662-668

Lang M, Hanslin HM, Kollmann J, Wagner T (2017) Suppression of an invasive legume by a native grass-high impact of priority effects. Basic Appl Ecol 22:20-27

Lenth RV (2016) Least-squares means: the R Package lsmeans. J Stat Softw 69:1-33

Levine JM, Adler PB, Yelenik SG (2004) A meta-analysis of biotic resistance to exotic plant invasions. Ecol Lett 7:975-989

Matías L, Quero JL, Zamora R, Castro J (2012) Evidence for plant traits driving specific drought resistance. A community field experiment. Environ Exp Bot 81:55-61

Mehlich A (1984) Mehlich 3 soil test extractant: a modification of Mehlich 2 extractant. Commun Soil Sci Plant Anal 15:1409-1416

Mertens M, Höss S, Neumann G, Afzal J, Reichenbecher W (2018) Glyphosate, a chelating agent-relevant for ecological risk assessment? Environ Sci Pollut Res 28:5298-5317

Oksanen JF, Blanchet G, Friendly M, Kindt R, Legendre P, McGlinn D, Minchin PR, O'Hara RB, Simpson GL, Solymos P, Stevens MHH, Szoecs E, Wagner H (2017) Vegan: Community Ecology Package. R package version 2.4-5

Parker IM, Harpole W, Dionne D (1997) Plant community diversity and invasion of exotic shrub Cytisus scoparius: testing hypotheses on invisibility and impact. In: Dunn PV, Ewing K (eds) Ecology and conservation of the Southern Puget Sound Prairie Landscape: the land conservancy. Nature Conservancy of Washington, Washington, pp 149-161

Paynter Q, Downey PO, Sheppard AW (2003) Age structure and growth of the woody legume weed Cytisus scoparius in native and exotic habitats: implications for control. J Appl Ecol 40:470-480

Peter DH, Harrington TB (2018) Effects of forest harvesting, logging debris, and herbicides on the composition, diversity and assembly of a western Washington, USA plant community. For Ecol Manag 417:18-30

Pinheiro J, Bates D, DebRoy S, Sarkar D, R Development Core Team (2013) nlme: linear and nonlinear mixed effects models. R package version 3.1-108

Potter KJB, Kritcos DJ, Watt MS, Leriche A (2009) The current and future potential distribution of Cytisus scoparius: a weed of pastoral systems, natural ecosystems and plantation forestry. Weed Res 49:271-282

PRISM Climate Group, Oregon State University. http://prism. oregonstate.edu. Created 4 Nov 2017

Prober SM, Lunt IE (2009) Restoration of Themeda australis swards suppresses soil nitrate and enhances ecological resistance to invasion by exotic annuals. Biol Invasions $11: 171-181$ 
R Core Team (2017) R: a language and environment for statistical computing. R Foundation for Statistical Computing, Vienna, Austria. https://www.R-project.org/

Richardson B, Whitehead D, McCracken IJ (2002) Root-zone water storage and growth of Pinus radiata in the presence of a broom understorey. NZ J For Sci 32(2):2008-2220

Ruesink J, Parker I, Groom M, Kareiva P (1995) Reducing the risks of nonindigenous species introductions. Bioscience 45:465-477

Shaben J, Myers JH (2009) Relationships between Scotch broom (Cytisus scoparius), soil nutrients, and plant diversity in the Garry oak savannah ecosystem. Plant Ecol 207:81-91

Slesak RA, Schoenholtz SH, Harrington TB, Strahm BD (2009) Dissolved carbon and nitrogen leaching following variable logging-debris retention and competing-vegetation control in Douglas-fir plantations of western Oregon and Washington. Can J For Res 39:1484-1497

Slesak RA, Harrington TB, D'Amato AW (2016) Invasive Scotch broom alters soil chemical properties in Douglas-fir forests of the Pacific Northwest, USA. Plant Soil 398:281-289

Thorne MS, Skinner QD, Smith MA, Rodgers JD, Laycock WA, Cerekci SA (2002) Evaluation of a technique for measuring canopy volume of shrubs. J Range Manag 55:235-241

Tutin TG, Heywood VH, Burges NA, Moore DM, Valentine DH, Walters SM, Webb DA (1968) Flora Europea, vol 2. Cambridge University Press, Cambridge, p 89

Vilà M, Espinar JL, Hejda M, Hulme PE, Jarošík V, Maron JL, Pergl J, Schaffner U, Sun Y, Pyšek P (2011) Ecological impacts of invasive alien plants: a meta-analysis of their effects on species, communities and ecosystems. Ecol Lett 14:702-708

Waterhouse BM (1988) Broom (Cytisus scoparius) at Barrington Tops, New South Wales. Aust Geogr Stud 26:239-248

Watt MS, Whitehead D, Mason EG, Richardson B, Kimberly MO (2003) The influence of weed competition for light and water on growth and dry matter partitioning of young Pinus radiata, at a dryland site. For Ecol Manag 183:363-376

Wearne LJ, Morgan JW (2004) Communtiy-level changes in Australian subalpine vegetation following invasion by the non-native shrub Cytisus scoparius. J Veg Sci 15:595-604

Wearne LJ, Morgan JW (2006) Shrub invasion into subalpine vegetation: implication for restoration of the native ecosystem. Plant Ecol 183:361-376

Weidenhamer JD, Callaway RM (2010) Direct and indirect effects of invasive plants on soil chemistry and ecosystem function. J Chem Ecol 36:59-69

Wheeler CT, Perry DA, Helgerson O, Gordon JC (1979) Winter fixation of nitrogen in Scotch broom (Cytisus scoparius). New Phytol 82:697-701

Wheeler CT, Helgerson O, Perry DA, Gordon JC (1987) Nitrogen fixation and biomass accumulation in plant communities dominated by Cytisus scoparius L. in Oregon and Scotland. J Appl Ecol 24:231-237

Williams PA (1981) Aspects of the ecology of broom (Cytisus scoparius) in Canterbury, New Zealand. NZ J Bot 19:31-43

Zhou T, Shi P, Hui D, Luo Y (2009) Global pattern of temperature sensitivity of soil heterotrophic respiration $(\mathrm{Q} 10)$ and its implications for carbon-climate feedback. J Geophys Res 114:1-9 